\title{
Role of Boards of Management (BOM) in Monitoring and Evaluation of Constituency Development Funded (CDF) Projects in Secondary Schools
}

\author{
Papa Osukuku Ben ${ }^{1 *}$, Zadock Obuchere Murundu² \\ ${ }^{1}$ St. Augustines Kamolo Secondary School. Box 135-50408, Kamuriai, Kenya \\ ${ }^{2}$ Tom Mboya University College Box 199-40300, Homabay Kenya \\ ${ }^{*}$ Corresponding Author \\ Papa Osukuku Ben
}

Article History

Received: 10.07.2019

Accepted: 20.07.2019

Published: 30.07 .2019

\begin{abstract}
Boards of Management (BOM) have a paramount role in ensuring successful implementation of Constituency Development Funded (CDF) projects in secondary schools in Kenya. They not only have direct but also indirect role in; oversight, management, monitoring and evaluation of the implementation of government funded projects in accordance with prescribed guidelines set by the Ministry of Education. Most of the Boards of Management don't perform this role fully leading to poor performance of CDF projects in secondary schools in Kenya. In Teso South Sub County of Busia County in particular, the situation is worse to the extent that most Principals have overpowered and ignored Boards of Management, leading to failure of CDF projects to achieve their desired goals in secondary schools. Some CDF projects are never completed due to embezzlement of funds by Principals. Other factors contributing to this scenario are yet to be established. The purpose of the study was to establish the role of Boards of Management in monitoring and evaluation of Constituency Development Funded (CDF) projects in public secondary schools. It consisted of 221 BOM members and 26 Principals of Secondary schools. Saturated sampling technique was used to sample out 26 Principals while Simple random sampling was used to sample out 72 BOM members. Data was collected by questionnaire and interview schedule. The study concluded that: Boards of Management (BOM) don't frequently inspect and evaluate financial records in schools. The study recommended that: Boards of Management (BOM) should be given full mandate of inspecting and evaluating all the school financial records to ensure that school funds are well utilized on the required projects.
\end{abstract}

Keywords: Role, Boards of Management, Monitoring, Evaluation, Constituency Development Fund, Projects, Public Secondary Schools

\section{INTRODUCTION}

Improved students' learning and achievement is strongly related to the way in which schools are managed. When the Board of Management (BOM) functions well, the school is well supervised and performs well [1]. BOM should have a pivotal role in the governance and management of schools for several reasons which include, but are not limited to, the following: Liaising with the head teachers in upholding the culture of the school; Maintaining school ethics, discipline and management of school funds; Proper management of general welfare of the school's staff and learners; Soliciting support for the school from the community and; Developing the quality and standards of education [2].

Boards of Management (BOM) are involved in sourcing and utilization of resources by ensuring that school funds are prudently managed [2]. Education Act Cap. 211 and Sessional Paper No. 1 of 2005 concur with this when they state that, Boards of Management should manage human and other resources in schools so as to facilitate smooth operations, infrastructural development and provision of teaching and learning materials [3]. Boards of Management BOM are also responsible for the management of projects sponsored by Constituency Development Fund (CDF) kitty. The role of BOM is to manage the school funds economically, efficiently and effectively on the behalf of the community in accordance with the financial memorandum by the Directorate of Education and the County Education Board [4].

BOM must have a three year financial plan approved by the County Director of Education and the County Education Board for a specific secondary school. The plan contains the school's expected expenditure within three financial years. ILO [5] points out

Copyright @ 2019: This is an open-access article distributed under the terms of the Creative Commons Attribution license which permits unrestricted use, distribution, and reproduction in any medium for non commercial use (NonCommercial, or CC-BY-NC) provided the original author and source are credited. 
that, Boards of Management (BOM) have a role in ensuring successful implementation of Constituency Development Funded (CDF) projects in secondary schools in Kenya. They tend to have an oversight in management and participate in monitoring and evaluation of the implementation of government funded projects in accordance with prescribed guidelines set by the Ministry of Education. Some of the CDF projects in Secondary schools include building of; classrooms, laboratories, toilets and latrines, administration blocks, dormitories, play grounds, dining halls, buying of; school buses, text books and other teaching and learning resources among others [6].

Despite the importance of having Boards of Management in schools, most of them don't perform their role to the fullest leading to poor performance of CDF projects in secondary schools in Kenya [2]. In Teso South Sub County of Busia County in particular, the situation is worse to the extent that most Principals have overpowered and ignored Boards of Management leading to failure of CDF projects to achieve their desired goals in secondary schools. Some of the CDF projects are never completed due to embezzlement of funds by Principals [7]. Other factors contributing to this scenario are yet to be established. Other factors contributing to this scenario are yet to be established, hence the need to conduct the current study that is meant to establish the role of Boards of Management in monitoring and evaluation of Constituency Development Funded (CDF) projects in public secondary schools.

\section{Objectives of the Study}

The study therefore aimed at exploring the role of Boards of Management in monitoring and evaluation of Constituency Development Funded (CDF) projects in public secondary schools.

\section{MATERIALS AND METHODOLOGY \\ Research Design}

Descriptive survey design was used in conducting this research as Ader, Van Marwik, Deltaan \& Beekman [8] describe descriptive survey as collecting data in order to test hypothesis or to answer questions concerning the current status of the subject of study. Descriptive survey design was chosen because it is appropriate for educational fact-finding as it yields a great deal of information, which is accurate. It also enables a researcher to gather data at a particular point in time and use it to describe the nature of the existing conditions [9]. The research aimed at gathering accurate information and characteristics that are observable in establishing the role of Boards of Management in Monitoring and Evaluation of Constituency Development Funded projects in Public Secondary Schools.

\section{Methodology}

Saturated sampling technique was used to sample out 26 Principals. Saturated sampling technique is a non - probabilitysampling technique in which all members of the target population are selected because they are too few to make a sample out of them [10]. Simple random sampling technique was used to select a sample size of 72 Members of Board of Management (33\% of the study population) as a third of the study population is the convenient sample size for a survey study [11]. Simple random sampling was used because it is a technique in which every member has an equal chance of being selected [12]. Study sample is shown in Table 1.

Table-1: Sample Frame

\begin{tabular}{|l|l|l|l|l|}
\hline $\begin{array}{l}\text { Category of } \\
\text { Respondents }\end{array}$ & Target Population & Sample Size & Percentage & Sampling Techniques \\
\hline Principals & 026 & 026 & $100 \%$ & Saturated \\
\hline BOM & 221 & 072 & $033 \%$ & Simple Random Sampling \\
\hline
\end{tabular}

Members of Board of Management questionnaire (MOBQ) was used to collect data. It had; open - ended and closed ended items so as to enable the researcher to gather data from a large number of respondents at a particular time [13]. Open - ended questions gathered in - depth information while closed - ended questions gave structured responses, which facilitated the ease of tabulation and analysis [8]. Principals' Interview Schedule (PIS) and Members of Board of Management questionnaire (MOBIS) were also used to gather data. The researcher preferred to use an interview schedules because they provide a free environment for the respondents to express themselves and even give additional information, which has not been catered for in the questionnaire [14].

\section{Reliability of Instruments}

To establish reliability of research instruments, a pilot study was carried out. It involved 2 Principals and 9 Members of Board of Management of secondary schools who were $4 \%$ of the study population [15]. The two tests were administered at an interval of two weeks. This was done so as to find out whether the terms used resonate with Principals and Members of Board of Management of secondary schools. The researcher then verified their content for accuracy, consistency, and ensured that ambiguous information was removed while deficiencies and weaknesses were noted and corrected in the final instruments. The respondents who participated in the pilot study were not involved in the final study. This method of establishing reliability of instruments is appropriate for the instruments that gather data which is qualitative in nature [14]. 


\section{Validity of the Instruments}

For validity of the instruments to be ensured three experts from the School of Education of Mount Kenya University examined the content of the instruments and advised the researcher on the face validity. Improvements were made according to the suggestions made by the experts before the instruments were finally taken into the field.

\section{Data Collection Procedures}

The researcher secured a research permit and a research authorization letter from the National Council for Science and Technology in the Ministry of Higher Education, Science and Technology through the School of Graduate Studies (S.G.S) of Mount Kenya University before proceeding to the field for data collection. The researcher then reported to the County Commissioner and the County Director of Education for Busia County and presented a copy of the letter of research authorization. Permission was then sought from the Principals and Members of Boards of Management of secondary schools sampled through written letters two weeks before the study was undertaken.

For effective administration of Members of Boards of Management Questionnaires (MOBQs), the researcher made a personal visit to the sampled Secondary Schools and gave both; Members of Boards of Management of secondary schools relevant instructions on how to fill questionnaires; he administered the questionnaires then requested the respondents to fill them carefully. Clarification was made on the items of the questionnaires where necessary. Finally, the researcher withdrew the completed questionnaires from Members of Boards of Management of secondary schools before he left for another school to avoid loss of some questionnaires.

The researcher then personally visited Principals and agreed with them on the convenient day and time they could meet for an interview. He informed them what he expected to research on in advance. When the material day for the interview reached, the researcher conducted the interview with both the Principals and the Members of the Boards of Management by reading all the questions found on the interview schedule systematically and individually while they answered appropriately. At the same time, the researcher was recording the responses in a reported speech form. All respondents were assured of confidentiality and anonymity when reporting.

\section{Methods of Data Analysis}

Data was analyzed by use of descriptive statistics. This included the use of frequency counts, percentages and means. Data gathered by open ended questions from questionnaires, Interviews and observation was organized, categorized and reported in emergent themes as defined by Watson [16], qualitative data analysis is systematic procedure followed in order to identify essential features, themes and categories. Data recorded in verbatim form from the interview with the Program Officer was also organized, categorized and reported according to emergent themes. The researcher finally reviewed the data again to locate additional evidence backing up each theme and compared the general themes across all data sources creating broader more consistent themes.

\section{RESULTS AND DISCUSSIONS}

Role of Boards of Management (BOM) of Secondary Schools in Monitoring and Evaluation of Performance of CDF Projects The study sought to establish role of Boards of Management (BOM) in monitoring and evaluation of performance of CDF projects in secondary schools. The findings were presented in Table 2.

Table-2: Principals' Views on the Role of Boards of Management (BOM) in Monitoring and Evaluating of Performance of CDF Projects in Secondary Schools

\begin{tabular}{|c|c|c|c|c|c|c|c|}
\hline No. & SUMMARY OF PRINCIPALS' VIEWS & \multicolumn{2}{|c|}{ AGREED } & \multicolumn{2}{|c|}{ UN DECIDED } & \multicolumn{2}{|c|}{ DISAGREED } \\
\hline & & No. & Percent & No. & Percent & No. & Percent \\
\hline 1. & $\begin{array}{l}\text { Boards of Management (BOM) Frequently inspect and } \\
\text { Evaluate Financial Records in Schools. }\end{array}$ & 03 & $04.00 \%$ & 04 & $06.00 \%$ & 65 & $90.00 \%$ \\
\hline 2. & $\begin{array}{l}\text { Boards of Management (BOM) are Committed and } \\
\text { Competent in Management of CDF Projects in Schools. }\end{array}$ & 58 & $80.00 \%$ & 00 & $00.00 \%$ & 14 & $20.00 \%$ \\
\hline 3. & $\begin{array}{l}\text { Boards of Management (BOM) Frequently Inspect and } \\
\text { Evaluate the Construction of CDF Projects in Schools. }\end{array}$ & 10 & $14.00 \%$ & 02 & $03.00 \%$ & 60 & $83.00 \%$ \\
\hline 4. & $\begin{array}{l}\text { Boards of Management (BOM) are Involved in the Vetting } \\
\text { of Contractors who construct CDF Projects in Schools. }\end{array}$ & 02 & $03.00 \%$ & 00 & $00.00 \%$ & 68 & $70.00 \%$ \\
\hline 5. & $\begin{array}{l}\text { Boards of Management (BOM) are Involved in the } \\
\text { Inspection and Evaluation of the Quality and Quantity of } \\
\text { Materials \& Equipment Bought for Construction of CDF } \\
\text { Projects in Schools. }\end{array}$ & 20 & $28 \%$ & 00 & $00.00 \%$ & 52 & $72.00 \%$ \\
\hline 6. & $\begin{array}{l}\text { Boards of Management (BOM) inspect and Evaluate the } \\
\text { Utilization and performance of CDF Projects Put in Place } \\
\text { in Schools. }\end{array}$ & 65 & $90 \%$ & 04 & $06.00 \%$ & 03 & $04.00 \%$ \\
\hline 7. & $\begin{array}{l}\text { Boards of Management (BOM) Frequently Inspect and } \\
\text { Evaluate Budgets for CDF Projects in Schools. }\end{array}$ & 58 & $80.00 \%$ & 00 & $00.00 \%$ & 14 & $20.00 \%$ \\
\hline
\end{tabular}


Data analysis in Table 2 reveals that; out of the 72 Board of Management (BOM) Members who participated in the study, Majority, Sixty five of them $(90.00 \%)$ disagreed with the statement that says that; Boards of Management (BOM) frequently inspect and evaluate financial records in schools. While very few, three of them $(04.00 \%)$ confirmed the statement to be true and just a handful, four of them $(06.00 \%)$ were undecided. Responses from an interview with Principals concurred with these findings when they were quoted saying:

"After drawing financial budgets for our schools we have to present and read it to the Boards of Management of our respective schools for approval only once in a year."

This implies that Boards of Management (BOM) don't frequently inspect and evaluate financial records in schools.

The study further reveals that; majority, Fifty eight (80.00\%) of the Board of Management (BOM) Members who participated in the study supported the statement that points out that; Boards of Management (BOM) are committed and competent in the management of CDF projects in schools. While a few of them Fourteen (20.00\%) did not confirm the statement to be true. This implies that Boards of Management (BOM) are fully committed and competent in management of CDF projects in schools.

Data analysis reveals that; majority of the Board of Management (BOM) Members, Sixty (83.00\%) disagreed with the statement that; Boards of Management (BOM) frequently inspect and evaluate the construction of CDF projects in schools. On the other hand, a few of them, Ten (14.00\%) confirmed the statement to be true, while a very small number, Two (03.00\%) was undecided. Responses from an interview with Board of Management (BOM) members concurred with these findings when they were quoted saying:

"We are only told the dates which construction of the projects is expected to commence, but not allowed to inspect and evaluate the progress of the construction itself so that we don't discover and question mistakes identified in construction easily."

This means that; Boards of Management (BOM) don't frequently inspect and evaluate the construction of CDF projects in schools.

The study findings reveal that; Most of Board of Management (BOM) Members who participated in the study Sixty Eight $(70.00 \%)$ disagreed with the statement that says that; Boards of Management (BOM) are involved in the vetting of contractors who construct CDF projects in schools. While only two of them $(03.00 \%)$ supported the statement to be true. This shows that; Boards of Management (BOM) are not fully involved in the vetting of contractors who construct CDF projects in schools.

Majority of the Board of Management (BOM) Members who participated in the study, Fifty two (72\%) disagreed with the statement that states that; Boards of Management (BOM) are involved in the inspection and evaluation of the quality and quantity of materials \& equipment bought for construction of CDF projects in schools. While a few of them, Twenty (28\%) concur with the statement. Responses from an interview with Board of Management (BOM) members concurred with these findings when they were quoted saying:

"Principals of our respective schools don't allow us to inspect and evaluate the quality and quantity of materials \& equipment bought for construction of CDF projects in schools leading to poor quality projects constructed."

This shows that the Boards of Management (BOM) are not fully involved in the inspection and evaluation of the quality and quantity of materials \& equipment bought for construction of CDF projects in schools.

The study reveals that; majority of Board of Management (BOM) Members who participated in the study, Sixty five (90\%), concur with the statement that points out that; Boards of Management (BOM) inspect and evaluate the utilization and performance of CDF projects put in place in schools. Few of them, Four $(06.00 \%)$ and a handful, Three $(04.00 \%)$ disagreed with the statement. This indicates that Boards of Management (BOM) inspect and evaluate the utilization and performance of CDF projects put in place in schools fully.

Data analysis reveals that; majority of the Board of Management (BOM) Members who participated in the study, Fifty eight (80\%) support the statement that says that; Boards of Management (BOM) frequently inspect and evaluate budgets for CDF projects in schools. While a small number, Fourteen $(20 \%)$ disagreed with the statement. This implies that; Boards of Management (BOM) frequently inspect and evaluate budgets for CDF projects in schools.

\section{CONCLUSION}

Based on the findings, the following were the Conclusions of the study; Boards of Management (BOM) don't frequently inspect and evaluate financial records in schools. Boards of Management (BOM) are committed and competent in management of CDF projects in schools. Boards of Management (BOM) don't frequently inspect and evaluate the construction of CDF projects in schools. Boards of Management (BOM) are not fully involved in the vetting of contractors who construct CDF projects in schools. 
Boards of Management (BOM) are not fully involved in the inspection and evaluation of the quality and quantity of materials \& equipment bought for construction of CDF projects in schools. Boards of Management (BOM) inspect and evaluate the performance of CDF projects put in place in schools fully. Boards of Management (BOM) frequently inspect and evaluate budgets for CDF projects in schools.

\section{RECOMMENDATION}

Based on the findings and conclusions, the following were the recommendations of the study; Boards of Management (BOM) should be given full mandate of inspecting all the school financial records to ensure that school funds are well utilized on the required projects. Boards of Management (BOM) should frequently inspect and evaluate the construction of CDF projects in schools. This will enable the construction exercise to take a very short period of time hence reducing the cost of construction.

Boards of Management (BOM) should be fully involved in the vetting of contractors who construct CDF projects in schools. This will enable schools to get qualified and efficient contractors to construct CDF projects.

Boards of Management (BOM) should be fully involved in the inspection and evaluation of the quality and quantity of materials \& equipment bought for construction of CDF projects in schools. This will ensure high quality projects are put up in schools.

\section{REFERENCES}

1. Mungai, M. (2009). Civil Society Organizations' Role in Enhancing Accountability and Community's Participation in the Management of Public Funds: The Case of the Constituency Development Fund in Kenya. Research Paper. International Institute for Social Studies.

2. CESA Team. (1994). Comprehensive Education Sector Analysis Draft Report. Nairobi: MoE/UNICEF Kenya Country Office.

3. Kenya. Presidential Working Party on Education and Manpower Training for the Next Decade and Beyond, Kamunge, J. M., \& Moi, D. A. (1988). Report of the presidential working party on education and manpower training for the next decade and beyond. Republic of Kenya.

4. Koech, D. (1999). Report of the commission of inquiry into the Education system of Kenya. Totally Integrated Quality Education and Training.

5. Barasa, F. S., \& Kaabwe, E. S. (2001). Fallacies in policy and strategies of skills training for the informal sector: evidence from the jua kali sector in Kenya. Journal of education and work, 14(3), 329-353.

6. Kibua, N. \& Mapesa, B. (2006). An Assessment of Management and Utility of Constituency Development Fund in Kenya. Nairobi: IPRAR

7. Kirima, N. (2003). Selection of CDFC, PMC and Conduct of Monitoring and Evaluation of CDF Projects in Kenya. Nairobi, Kenya: Government Printer.

8. Ader, H. J. Van Marwik, H. W. Deltaan, M. \& Beekman, A. (2008). Advising on Research Methods: A Consultant's Comparison. Huizen, the Netherlands: Johannes Van Kessel Publishers.

9. Cohen, L. Manion, H. \& Morizon, K. (2000). Research Methods in Education (5 $5^{\text {th }}$ Edition, London: Routledge Falmer.

10. Borg, R.W. \& Gall, J.P. (2007). Educational Research: An Introduction. New York: Longman Publishers.

11. Mugenda, O.M. \& Mugenda, A. G. (2003). Research Methods: Quantitative and Qualitative Approaches. Nairobi: African Centre for Technology Studies Press.

12. Bartlett, J.E, Kotrlik, J. W. \& Higgs, C.C. (2001). Organizational Research: Determining Appropriate Sample Size for Survey Research. Information Technology, Learning and Performance Journal, 19 (1) 43-50.

13. Ngumbo, H. (2006). Guidelines on Special Study Paper (SSP). Nairobi: Kenya Institute of Special Education.

14. Creswell, J. W. \& Miller, D. L. (2000). Determining Validity in Qualitative Inquiry. Theory into Practice, 39 (3), 124-131

15. Chambers, R. L., \& Skinner, C. J. (Eds.). (2003). Analysis of survey data. John Wiley \& Sons.

16. Watson, G. (1987). Writing a thesis: a guide to long essays and dissertations. Addison-Wesley Longman Limited. 